\title{
ANTIOXIDANT EFFECT OF POLYHERBAL FORMULATION IN ISOPRENALINE HYDROCHLORIDE INDUCED MYOCARDIAL INFARCTION IN RATS
}

\author{
KAVITHA P. ${ }^{*}$, SOWMIA C. ${ }^{*}$ \\ PG and Research Department of Biochemistry, Dr. NGP Arts and Science College, Coimbatore, Tamilnadu 641048, India \\ Email: kavirajan83@yahoo.com
}

Received: 27 May 2017 Revised and Accepted: 31 Aug 2017

\section{ABSTRACT}

Objective: Myocardial infarction (MI) continues to be a major public health problem in the world. The prepared polyherbal formulation (PHF) exhibit cardioprotective effects by several mechanisms. The objective of the research was to evaluate the antioxidant effect of a polyherbal formulation in isoprenaline hydrochloride (ISO) induced myocardial infarction in rats.

Methods: Oxidative stress and myocardial infarction was induced by administration of isoprenaline hydrochloride ( $25 \mathrm{mg} / \mathrm{kg}$ ) for $2 \mathrm{~d}$. The degree of protection was determined by measuring the levels of lipid peroxidation (LPO), enzymatic antioxidants (superoxide dismutase-SOD, Catalase, Glutathione peroxidase) and non-enzymatic antioxidants (Vitamin C, E and reduced glutathione-GSH).

Results: Two different doses ( $250 \mathrm{mg}$ and $500 \mathrm{mg} / \mathrm{kg}$ body wt) of the formulation was used to prove the cardioprotective effect. Pretreatment with polyherbal formulation significantly $(\mathrm{P}<0.05)$ lowered LPO and elevated the enzymatic and non-enzymatic antioxidants in heart homogenate.

Conclusion: The polyherbal formulation exhibited cardioprotective activity, which could be attributed to its antioxidant activity.

Keywords: Myocardial infarction, Polyherbal formulation, Isoprenaline hydrochloride, Oxidative stress, Free radicals

(C) 2017 The Authors. Published by Innovare Academic Sciences Pvt Ltd. This is an open access article under the CC BY license (http://creativecommons.org/licenses/by/4.0/) DOI: http://dx.doi.org/10.22159/ijpps.2017v9i10.20310

\section{INTRODUCTION}

The World Health Organization estimates that $80 \%$ of the people in developing countries of the world rely on traditional medicines. Medicinal plants and plant-derived products are used as medicines in a large group of the world population. Plants exert useful pharmacological activity in the therapeutic treatment of various disorders. [1]. Cardio Vascular Diseases (CVD) are the number one cause of death globally: more people die annually from CVD's than from any other cause [2]. Millions of people are taking betaadrenoreceptor blocker drugs esp., isoprenaline hydrochloride, for reducing blood pressure and cholesterol which may lead to serious side effects. It is no surprise, then, that the use of alternative medicine, such as botanicals and nutritional supplements, has become popular for curing various diseases [3]. The new formulation gives a positive and consistent pharmacological strategy that can meet the valid changes of medical science. Herbal medicines are of great importance to the health of individuals and communities. Synergy is an important concept in herbal pharmacology. It was based on chemical complexity. It applies if the action of a chemical mixture is greater than the arithmetical sum of the actions of the mixture's components. Oxidative stress is the condition when the body is under the onslaught of free radicals due to which the free radicals encounter cellular molecules such as lipids, proteins, and DNA and they knocked out electrons from the molecules as well and damaged them. Some free radicals arise normally during metabolism. The oxidative stress involved in the development and pathogenesis of a wide variety of diseases ranging from hypertension, diabetes, arthritis, and related disorders. The oxidative process is one of the most important routes for producing free radicals in food, drug, and even in the living system [4]

From the literature survey and through folk medicine we found that the plants Allium sativum, Trigonella foenum-graecum and Linum usitatissimum were found to posses cardioprotective effect [5]. Hence based on their anti-oxidant activity a polyherbal formulation (PHF) containing the three plants in 1:2:1 ratio was used for the study. To the best of our knowledge, there has been no report on the potential antioxidant effects of the polyherbal formulation for protection of cardiac cells from Isoprenaline hydrochloride induced cardiotoxicity.

\section{MATERIALS AND METHODS}

\section{Experimental animals}

Wistar rats of either sex weighing 140-160 g were obtained from animal house-PSG Institute of Medical Sciences and Research, Coimbatore and were used for the study. Rats were maintained on a standard diet and water ad libitum. All animals were housed at ambient temperature $\left(21 \pm 1^{\circ} \mathrm{C}\right)$ and relative humidity $\left(55 \pm 5{ }^{\circ} \mathrm{C}\right)$ with fixed $12 \mathrm{~h} / 12 \mathrm{~h}$ light/dark cycle. Animals had free access to standard pellet diet and water were given ad libitum. The experimental protocol was approved by institutional Animal Ethical Committee (No: 300/2015/IAEC).

\section{Drugs and chemicals}

Isoprenaline hydrochloride was procured from Sigma chemicals Co (St. Louis, mo, USA). All other chemicals used for the study were of analytical grade.

\section{Preparation of polyherbal formulation}

All the plant specimens were collected from local departmental store, Coimbatore, Tamil Nadu, India and was taxonomically identified by Dr. Murugan, Scientist, Botanical Survey of India, Coimbatore, Tamil Nadu, India and a voucher specimen [No: BSI/SRC/5/23/2017/3182,BSI/SRC/5/23/2015/1690,BSI/SRC/5/ $23 / 2015 / 1691]$ respectively was retained as a herbarium in the same department for future reference. The freshly cut plants were dried in the shade with active ventilation at ambient temperature and pulverized to a coarse powder using a mechanical grinder and extracted with $70 \%$ ethanol using soxlet apparatus. The miscella was then concentrated using a vacuum rotary evaporator under reduced pressure. The polyherbal formulation containing extracts of Allium sativum (bulbs), Trigonella foenum graecum (seeds) and Linum usitatissimum (seeds) are well-known plants and possess antioxidant property. The ethanolic extract of the three plant specimens in the ratio $(1: 2: 1)$ was prepared and used for the study in the dosage of ( $250 \mathrm{mg} / \mathrm{kg}$ and $500 \mathrm{mg} / \mathrm{kg}$ body weight). 


\section{Experimental design}

Group I: Animals were treated with normal saline alone.

Group II: Animals were subcutaneously injected with Isoprenaline hydrochloride $\left(25 \mathrm{mg} / \mathrm{kg}\right.$ body weight) for a period of $2 \mathrm{~d}$ ie., on $29^{\text {th }}$ and $30^{\text {th }}$ day at $24 \mathrm{hr}$ interval.

Group III: Animals were treated with standard Atorvastatin (10 $\mathrm{mg} / \mathrm{kg}$ ) for a period of $28 \mathrm{~d}$ and subcutaneously injected with Isoprenaline hydrochloride ( $25 \mathrm{mg} / \mathrm{kg}$ body weight) for a period of $2 \mathrm{~d}$ ie., on $29^{\text {th }}$ and $30^{\text {th }}$ day at $24 \mathrm{hr}$ interval.

Group IV: Animals were treated with PHF (250 mg/kg) for a period of $28 \mathrm{~d}$ and subcutaneously injected with Isoprenaline hydrochloride $\left(25 \mathrm{mg} / \mathrm{kg}\right.$ body weight) for a period of $2 \mathrm{~d}$ ie., on $29^{\text {th }}$ and $30^{\text {th }}$ day at $24 \mathrm{hr}$ interval.

Group V: Animals were treated with PHF $(500 \mathrm{mg} / \mathrm{kg})$ for a period of $28 \mathrm{~d}$ and subcutaneously injected with Isoprenaline hydrochloride ( $25 \mathrm{mg} / \mathrm{kg}$ body weight) for a period of $2 \mathrm{~d}$ ie., on $29^{\text {th }}$ and $30^{\text {th }}$ day at $24 \mathrm{hr}$ interval.

After $30 \mathrm{~d}$ of the experimental period (i.e., on 31 st day), all animals were anaesthetized and sacrificed, blood samples collected and heart was isolated. The heart tissue homogenate was prepared in 6.1 $\mathrm{M}$ Tris $\mathrm{HCl}$ buffer $\mathrm{pH} 4$ were used for the determination of lipid peroxides [6], Superoxide dismutase [7], Catalase [8], Glutathione peroxidase [9], Vitamin C[10], Vitamin E [11] and Reduced Glutathione [12].

\section{Statistical analysis}

The values were expressed as mean \pm SD. Data were analyzed for the statistical significance by one-way analysis of variance (ANOVA) followed by the group means were compared with Duncan's new multiple range test using a statistical software Agres stat version 3.1 and value of $\mathrm{P}<0.05$ was considered to indicate a significant difference between the groups.

\section{RESULTS AND DISCUSSION}

The Indian system of medicine, especially Ayurveda, has several medicinal plants with proven beneficial claims towards these pathological conditions. However, the potential of herbal drugs as defined therapeutic agents is undetermined by the difficulty in standardization, pharmacodynamics and pharmacokinetics of these multicomponent mixtures and also the lack of enough experimental data. Medicinal plants need to be investigated scientifically and rigorously to define their role in prevention and treatment of cardiovascular conditions and to stimulate the future pharmaceutical development of therapeutically beneficial herbal drugs. Taking this consideration in our mind, we have planed this study for evaluation of the protective effect of polyherbal formulation especially with a definite aim of cardioprotection

The present study was aimed to evaluate the antioxidant effect of the polyherbal formulation in isoprenaline hydrochloride induced myocardial infarction in rats. An increased risk of coronary heart disease and atherosclerosis is associated with a decrease in the levels of enzymatic and non-enzymatic antioxidants.

Table 1: Effect of pretreatment with polyherbal formulation on Lipid peroxidation in serum and heart homogenate

\begin{tabular}{llll}
\hline S. No. & Group & Lipid peroxidation $(\boldsymbol{\mu m o l e s} / \mathbf{m g}$ tissue) & LPO heart \\
\cline { 3 - 4 } & & LPO serum & $6.40 \pm 0.37^{\mathrm{a}}$ \\
\hline I & Normal Control & $3.44 \pm 0.44^{\mathrm{a}}$ & $9.38 \pm 0.15^{\mathrm{b}}$ \\
II & ISO Control & $5.97 \pm 0.16^{\mathrm{b}}$ & $6.67 \pm 0.31^{\mathrm{a}}$ \\
III & Standard Control & $3.46 \pm 0.42^{\mathrm{a}}$ & $7.10 \pm 0.31^{\mathrm{c}}$ \\
IV & PHF (250 mg/kg) & $4.93 \pm 0.09^{\mathrm{c}}$ & $6.72 \pm 0.10^{\mathrm{a}}$ \\
V & PHF (500 mg/kg) & $4.23 \pm 0.08^{\mathrm{d}}$ & \\
\hline
\end{tabular}

Values are mean $\pm S D$ of three samples in each group, a-f Mean values within a column no common superscript differ significantly at $5 \%$ by DMRT.

\section{LPO-lipid peroxidation}

A number of pathophysiological mechanisms have been used to explain the ISO-induced myocardial damage, including altered permeability, increased turnover of norepinephrine, and generation of cytotoxic free radicals on autoxidation of catecholamine. Free radical-mediated lipid peroxidation and consequent changes in membrane permeability are the primary factors for cardiotoxicity induced by ISO [13]. A significant $(\mathrm{P}<0.05)$ increase in the levels of lipid peroxides in serum and heart on ISO administration indicates enhanced lipid peroxidation by free radicals. The increased levels of TBA reactive substances indicate the excessive formation of free radicals and activation of lipid peroxidation system resulting in irreversible damage to the heart in animals subjected to ISO stress. The significant increase observed in the levels of lipid peroxides in serum and heart of ISO infracted rats compared to control, was in accordance with the observation of previous reports [14].

Table 2 shows the levels of enzymatic antioxidants SOD, Catalase and Glutathione peroxidase (GPx). Administration of ISO significantly $(\mathrm{P}<0.05)$ decreased the levels of these enzymes in group II rats. Pretreatment with PHF protected the cells from damaged caused by free radicals and that is significantly $(\mathrm{P}<0.05)$ visible from the levels of these enzymes in group IV and $V$ rats similar to standard control (group III) rats.

The major subcellular antioxidant defences are Reactive Oxygen Species (ROS) scavenging enzymes such as SOD, Catalase and GPx. Increased levels or activation of these endogenous antioxidants or enzymes have been shown to protect cells against oxidative damage.

Table 2: Effect of pretreatment with polyherbal formulation on enzymatic antioxidant enzymes in heart homogenate

\begin{tabular}{lllll}
\hline S. No. & Group & Superoxide dismutase & Catalase & Glutathione peroxidase \\
\cline { 2 - 5 } & & ( $\boldsymbol{\mu \text { moles } / \mathbf { m g } \text { tissue } )}$ & \\
\hline I & Normal Control & $1.42 \pm 0.44^{\mathrm{a}}$ & $9.97 \pm 0.31^{\mathrm{a}}$ & $10.77 \pm 0.95^{\mathrm{a}}$ \\
II & ISO Control & $0.55 \pm 0.10^{\mathrm{a}}$ & $2.93 \pm 0.15^{\mathrm{b}}$ & $4.63 \pm 0.65^{\mathrm{b}}$ \\
III & Standard Control & $1.10 \pm 0.20^{\mathrm{a}}$ & $8.07 \pm 0.76^{\mathrm{c}}$ & $9.10 \pm 0.78^{\mathrm{c}}$ \\
IV & PHF (250 mg/kg) & $0.70 \pm 0.06^{\mathrm{a}}$ & $5.37 \pm 0.60^{\mathrm{d}}$ & $6.53 \pm 0.81^{\mathrm{d}}$ \\
V & PHF (500 mg/kg) & $0.91 \pm 0.04^{\mathrm{a}}$ & $7.37 \pm 0.31^{\mathrm{e}}$ & $8.07 \pm 0.67^{\mathrm{e}}$ \\
\hline
\end{tabular}

Values are mean \pm SD of three samples in each group, a-f Mean values with in a column no common superscript differ significantly at $5 \%$ by DMRT. 
Table 3: Effect of pretreatment with polyherbal formulation on non-enzymatic antioxidants in heart homogenate

\begin{tabular}{lllll}
\hline S. No. & Group & Vitamin C & Vitamin E & Reduced glutathione \\
\cline { 3 - 5 } & & $(\boldsymbol{\mu g} / \mathbf{m g}$ tissue $)$ & & $3.70 \pm 0.26^{\mathrm{a}}$ \\
\hline I & Normal Control & $1.77 \pm 0.12^{\mathrm{a}}$ & $2.14 \pm 0.40^{\mathrm{a}}$ & $0.78 \pm 0.04^{\mathrm{b}}$ \\
II & ISO Control & $0.80 \pm 0.08^{\mathrm{b}}$ & $1.19 \pm 0.18^{\mathrm{b}}$ & $2.65 \pm 0.23^{\mathrm{c}}$ \\
III & Standard Control & $1.33 \pm 0.09^{\mathrm{c}}$ & $1.79 \pm 0.07^{\mathrm{c}}$ & $1.57 \pm 0.32^{\mathrm{d}}$ \\
IV & PHF (250 mg/kg) & $0.94 \pm 0.05^{\mathrm{d}}$ & $1.54 \pm 0.07^{\mathrm{c}}$ & $2.43 \pm 0.40^{\mathrm{c}}$ \\
V & PHF (500 mg/kg) & $1.27 \pm 0.06^{\mathrm{c}}$ & $1.78 \pm 0.03^{\mathrm{c}}$ & \\
\hline
\end{tabular}

Values are mean \pm SD of three samples in each group, a-f Mean values with in a column no common superscript differ significantly at $5 \%$ by DMRT

Table 3 shows the levels of non-enzymatic antioxidants vitamin C, vitamin $\mathrm{E}$ and reduced glutathion in heart homogenate of experimental rats. These antioxidants were significantly $(\mathrm{P}<0.05)$ decreased in ISO treated rats when compared to control. This may be associated with the elevation in the generation of Reactive Oxygen Species. Pretreatment with polyherbal formulation significantly $(\mathrm{P}<0.05)$ increased the levels of vitamin $\mathrm{C}$ and vitamin $\mathrm{E}$ in group IV and $\mathrm{V}$ rats pronouncing the cushioning effect of free radicals produced during ISO-induced myocardial infarction. Evidences suggest that oxidative cellular injury is caused by free radicals contributed to the development of cardiomyopathy [15].

Due to increased lipid peroxidation, glutathione levels were lowered significantly in hearts of group II rats, which was maintained to near normal levels in PHF and standard pretreated groups (III, IV and V). Decreased glutathione level may be due to its increased utilization in protecting SH groups containing proteins from the action of free radicals. Glutathione participates directly in the destruction of hydrogen peroxide and also promotes the formation of reduced form of ascorbate, which has high antioxidant activity [16].

\section{CONCLUSION}

The results obtained in the present investigation indicates that administration of PHF may offer protection against ISO induced myocardial infarction by decreasing LPO and increasing the levels of enzymatic and non-enzymatic antioxidants. The natural antioxidants were found to be increased in PHF pretreated rats when compared to Group II rats. The mechanism of cardioprotective activity may be attributed to the antioxidant activity of polyherbal formulation. However, the components responsible for the antioxidant activity are currently unclear. Therefore, further investigation is needed to isolate and identify the antioxidant compounds present in the polyherbal formulation.

\section{AUTHORS CONTRIBUTION}

1. P. Kavitha: As a first author involved in designing of the work, Data collection, data analysis and data interpretation and drafting of the article.

2. Dr. C. Sowmia: As a co-author involved in the planning of the experiment, data interpretation and critical revision of the article.

\section{CONFLICTS OF INTERESTS}

The authors are thankful to the management KMCH and Dr NGP group of institutions for providing all facilities to carry out the research work.

\section{REFERENCES}

1. Farnsworth NR, Akerele O, Bingel AS, Soejarto DD, Guo ZG. Medicinal plants in therapy. Bull WHO 1985;63:965-81.
2. Halliwell B, Aruoma OI. DNA damage by oxygen derived species. Its mechanism and measurement in mammalian systems. FEBS Lett 1991;281:9-19.

3. Dhevi R, Elango V, Gayathri K. Cardioprotective and antioxidant effects of seeds of Spermacoce hispida linn., on isoproterenol induced myocardial infarction in rats. W J Pharm Pharm Sci 2014;3:1150-8.

4. Deepa P, N Kannappan. Comparative in vitro antioxidant studies of aqueous solution of formulated poly herbal formulation with marketed preparation. Scholar Res Lib Pharm Lett 2012;4:1515-17.

5. Rajalakshmy, Ramya Pydi S, Kavimani. Cardioprotective medicinal plants-a review. Int J Pharm Inven 2011;1:24-41.

6. Das S, Vasisht S, Senhlata C, Das N, Srivastava LM. Correlation between total antioxidant status and lipid peroxidation in hypercholesterolemia. Curr Sci 2000;78:486-7.

7. Sinha AK. Colorimetric assay of catalase. Anal Biochem 1972;47:389-94.

8. Ellman GL, Fiches FT. Quantitative determination of peptides by sulfhydryl groups. Arch Biochem Biophy 1959;82:70-2.

9. Omaye DW, Emery G, Maynard JE. Selected methods for the determination of ascorbic acid in animal cells, tissues, and fluids. Methods Enzymol 1979;62:3-11.

10. Varley H, Gowenlock AH, Bell M. Practical clinical biochemistry. William Heineman Medical Books Ltd: London; 1981;2:222.

11. Reitman S, Frankel S. A colorimetric method for determination serum glutamic oxaloacetic and glutamic pyruvic transaminases. Am J Clin Pathol 1957;28:56-63.

12. Moron MS, Defierre JW, Mannervak D. Levels of glutathione, glutathione reductase and glutathione-S-transferase activities in rat lung and liver. Biochem Biophys Acta 1979;582:67-8.

13. Sun DQ Nguyen N, Degrado TR. Ischemia induces translocation of the insulin responsive glucose transporter GLUT- 4 to the plasma membrane of the cardiomyocytes. Cirt Res 1994;89:793.

14. Jayalakshmi R, Niranjali Devaraj S. Cardioprotective effect of crataegus on isoproterenol induced myocardial infarction in rats. J Pharm Pharmacol 2004;56:921-6.

15. Nnodim John Kennedy, Dike Ndudin Joy, Elendu Humphery Ndubueze, Nwagbaraocha Melvina, Egbuobi Richard, Onyeze vitus. Antioxidant and cardioprotective effect of cocnut water against doxirubicin induced cardiomyopathy. J Krishna Inst Med Sci Univ 2013;2:37-41.

16. Chabukswar AR, Kuchekar BS, Jagdale SC, Lokhande PD, Raut CG. Cardioprotective activity of Inula racemosa. Int J Chem Sci 2010;8:1545-52.

\section{How to cite this article}

- Kavitha P, Sowmia C. Antioxidant effect of polyherbal formulation in isoprenaline hydrochloride induced myocardial infarction in rats. Int J Pharm Pharm Sci 2017;9(10):273-275. 